\title{
Oksana Shelomovska
}

$\mathrm{PhD}$ is State Regulation, Associate Professor

Dniprovsk State Technical University, Kamianske, Ukraine

o_nix@ukr.net

ORCID: 0000-0003-3409-9435

\section{Liudmyla Sorokina}

PhD in Sociology, Associate Professor

Dniprovsk State Technical University, Kamianske, Ukraine

sludmila1906@gmail.com

ORCID: 0000-0003-4875-2896

\section{Maryna Romaniukha}

$\mathrm{PhD}$ in Germanic Languages, Associate Professor

Dniprovsk State Technical University, Kamianske, Ukraine

Romanuks@ukr.net

ORCID: 0000-0001-7623-2690

\section{Kostiantyn Bohomaz}

Doctor of Historical Sciences, Full Professor, Head of the department of Sociology

Dniprovsk State Technical University, Kamianske, Ukraine

socis@i.ua

ORCID: 0000-0002-6469-0958

\section{THE ICT POTENTIAL FOR TEACHING SOCIOLOGICAL COURSES}

\begin{abstract}
The present state of information and communication technologies in teaching sociological disciplines defined promising directions of improving interaction between teacher and student through wider implementation of ICTs in the educational process. The authors elaborate on advantages and disadvantages of using ICT in teaching sociological disciplines. The paper discusses results of a sociological survey, held in Dniprovsk State Technical University with the aim to analyze the scope of ICT use in teaching. ICTs are efficiently applied in various classrooms with different content, in case professors evaluate the quality of mastering learning materials and students' independent work. Modern lecturers of sociology widely use individual digital materials to support classes (presentations, display materials) and students' independent work (digital textbooks, assignments, tests); recommend as basic and additional sources of information various e-manuals and related sites; some digital media training applications from available collections, university repository, electronic curricula and resources from research databases. The use of the aforementioned ICTs in teaching sociology enhances cognitive activity of students, develops research skills, creative potential, promotes more efficient formation of general and specific competencies. The use of ICTs in the teaching social sciences is the evidence of competences of modern teachers.
\end{abstract}

Keywords: ICTs, multimedia; Internet resources; thematic websites; electronic manuals, computer programs; computer testing

Introduction and statement of the problem. Nowadays, with global informatization the use of information and communication technologies in teaching of social sciences is an objective necessity. The introduction of ICTs into the educational process is one of the major challenges facing teachers of higher educational institutions of Ukraine and the world. The enrichment of educational process with innovative ICTs helps create a favorable atmosphere between teachers and students, thus contributing to student-centered learning. In the future professors will increasingly serve as facilitators, they will help students to find reliable training materials, and not so much as people who simply transmits knowledge. The modern teacher must be an expert in modern educational techniques, technologies and ways to independently shape teaching process in the context of specific practical educational activities. Therefore, sociology professors have to be well aware of the trends in the 
information flow and to be able to draw students' attention to them. Here ICTs provide almost unlimited possibilities of search, selection, synthesis, structuring and presentation of material. The use of ICTs, Internet, computers and mobile devices in the classroom makes the teaching process more flexible, strictly differentiated and individually-oriented.

According to studies, the human memory can keep 25\% of the audio information, 33\% of visual and audio, and up to $75 \%$ of the material can be kept involving active learning. Active and involved study of sociological subjects can be provided via ICTs in classroom and during independent work. They increase the quality of education, promote the formation of core competencies, invite teachers and students into the modern information environment, promote self-fulfillment and self-identity of the teacher and the student. Improving the efficiency and consistency of the educational process is achieved through the integrated use of various software and hardware and the use of methods and techniques of active learning. That is why the use of ICTs in the teaching of social sciences is an important part of modern educational paradigm.

The analysis of previous research. Implementation and use of ICTs in educational process has been gaining importance lately. This, in turn, determines the academic interest in the topic. First of all, it should be noted that scientific discourse is abundant with research into existing practices and ways to enhance the use of ICT in the teaching of humanities in higher education. In particular, there should be mentioned publications by A. Karalkin, V. Golota, A. Zymovets, O.Podlinyayeva, Y. Alferov, A. Veryaskyna G. Neshovorova, E. Lubnina, D. Yashnov, Y. Chebotareva, N. Yehoryenkova and others.

The analysis of ICT and multimedia use in teaching sociological disciplines is discussed by A. Slobodyanyuk. Given the fact that the computer has become a natural part of the environment and in the perception of the new generation is a permanent feature of reality, researcher admits the growing need to use Internet technologies in the teaching of social sciences. Teachers should enable students to master the technology and use them creatively. In classes teachers explain and show to students how to look up in the Internet the information reflecting the results of the latest research on various problems of sociology (Slobodianiuk, 2007).

L. Ditkovska analyzed the ways of developing ICT competence in university students of the course Social Work. In order to improve the efficiency of developing ICT-enhanced professional skills, teachers should use presentations during lectures, develop electronic versions of tasks for classroom laboratory work and independent studies, develop electronic tests for thematic and modular control of knowledge, in particular, in LMS Moodle (Ditkovska, 2013).

Features of use of video in teaching sociological disciplines were explored by N. Korytnykova. In particular, the use of video promotes the interpretation of both abstract theoretical ideas and applied social tasks. Through watching films social reality is represented to students as a more substantial and comprehensive object of sociology, which helps their professional development (2).

Possible use of Internet technologies in the teaching of social sciences are presented by S. Schyehlova. The researcher considers the Internet as a source of information and notes that today the network embraces a vast number of sites that contain many different materials for secondary analysis. This enriches cognitive culture of students, increases their interest in conducting their own research and present their materials. Teachers in an Internet classroom run all the educational activities (Shchiehlova, 2002)

Exploring innovative approaches in teaching sociology, N. Malikova found that qualitative approach in teaching sociology in modern conditions provides for the collection of information in social media networks where we can observe interactive collaboration of respondents, experts, representatives of various reference modal and social groups. What's 
fundamentally new is the ability of democratic communication and obtaining relevant information, without restrictions in social status on portals, forums, sites, from collective and individual users of the global network (Malikova, 2011).

A.Vorontsov and V. Lukyanov discuss ways of transferring traditional lectures on sociology into multimedia mode and the use of electronic anthologies in order to manage students' independent work. It is argued that multimedia technology permit to integrate many kinds of information harmoniously, which stimulates cognitive activity of students, increases motivation to learn; promotes the development of skills of teamwork and collective creativity; set the stage for a mini-debate; improve the lecture assimilation, as students interpret information simultaneously on rational, emotional, conscious and unconscious level of perception (Vorontsov, Lukianov, 2011).

However, despite the deep interest in ICTs, modern education researchers tend to focus on advantages and disadvantages of using ICT in teaching. The possibilities of using ICTs in teaching social sciences has not been studied carefully and we can stress the lack of attention of modern researchers to this topic. All this suggests that the study of available and potential uses of ICTs in teaching sociology may reveal new perspectives in improving the quality of higher education and in integrating Ukraine into the global scientific and educational space.

Formulating the goal and objectives. The purpose of the article is to analyze the current state of ICT usage in teaching sociological disciplines direction and identifying promising areas of improvement in teacher-student interaction through wider implementation of ICT in the educational process.

Statement of research results. To analyze the scope of ICT use in teaching we will consider the results of a sociological survey, held in Dniprovsk State Technical University. The survey intended to reveal the scope of ICT use various fields of teaching. This study was carried out in the framework of the international project «International Research Network for study and development of new tools and methods for advanced pedagogical science in the field of ICT instruments, e-learning and intercultural competences». Project is financed by the European Commission under the 7th Framework Programme, within the Marie Curie Actions International Research Staff Exchange Scheme. Project participants are universities in, Poland, the Czech Republic, the Slovak Republic, Portugal, Spain, the Netherlands, Ukraine, the Russian Federation and Australia. One of representatives from Ukraine in this project is the Dniprovsk State Technical University. It is an average university of Ukraine which permits us to apply research results to a variety of Ukrainian Universities.

The survey was conducted by a specially designed electronic questionnaire, which was spread among teachers and heads of departments in DSTU. The survey involved 53 university employees, of which $89 \%$ is scientific and teaching staff (59\% - associate professors, $26 \%$ teachers, $4 \%$ - professors) and $11 \%$ - heads of departments. Empirical research base allows to draw some conclusions about the peculiarities of using ICT in teaching.

Thus, it was established that in their own educational activities, most respondents are using self-developed digital materials to support classes (presentations, demos) - 83\%; selfdeveloped digital educational materials for individual students' independent work (digital textbooks, assignments, tests) $-73.6 \%$ and electronic manuals (library, university, library) as recommended additional and major sources - 66\% and $54.7 \%$ respectively (Fig. 1).

The data in the Figure prompt that professors are also inclined to use thematic sites, media objects, (fragments of films, television and radio programs) and some digital media training facilities from available collections. Nearly a third of current teachers use elements of these ICTs in their work. A quarter of the surveyed teachers use the university repository and educational curricula, and the fifth - resources of research databases that are part of the university subscription, elements of virtual items, such as computer models to solve problems and research into the objects in question. However, despite the relatively wide popularity of 
ICTs in the teaching community, the least used instruments are summaries of updatable journals (15.1\%), electronic courses as a result of students' project work (15.1\%) and ecourses, personally developed by professors (3.8\%).

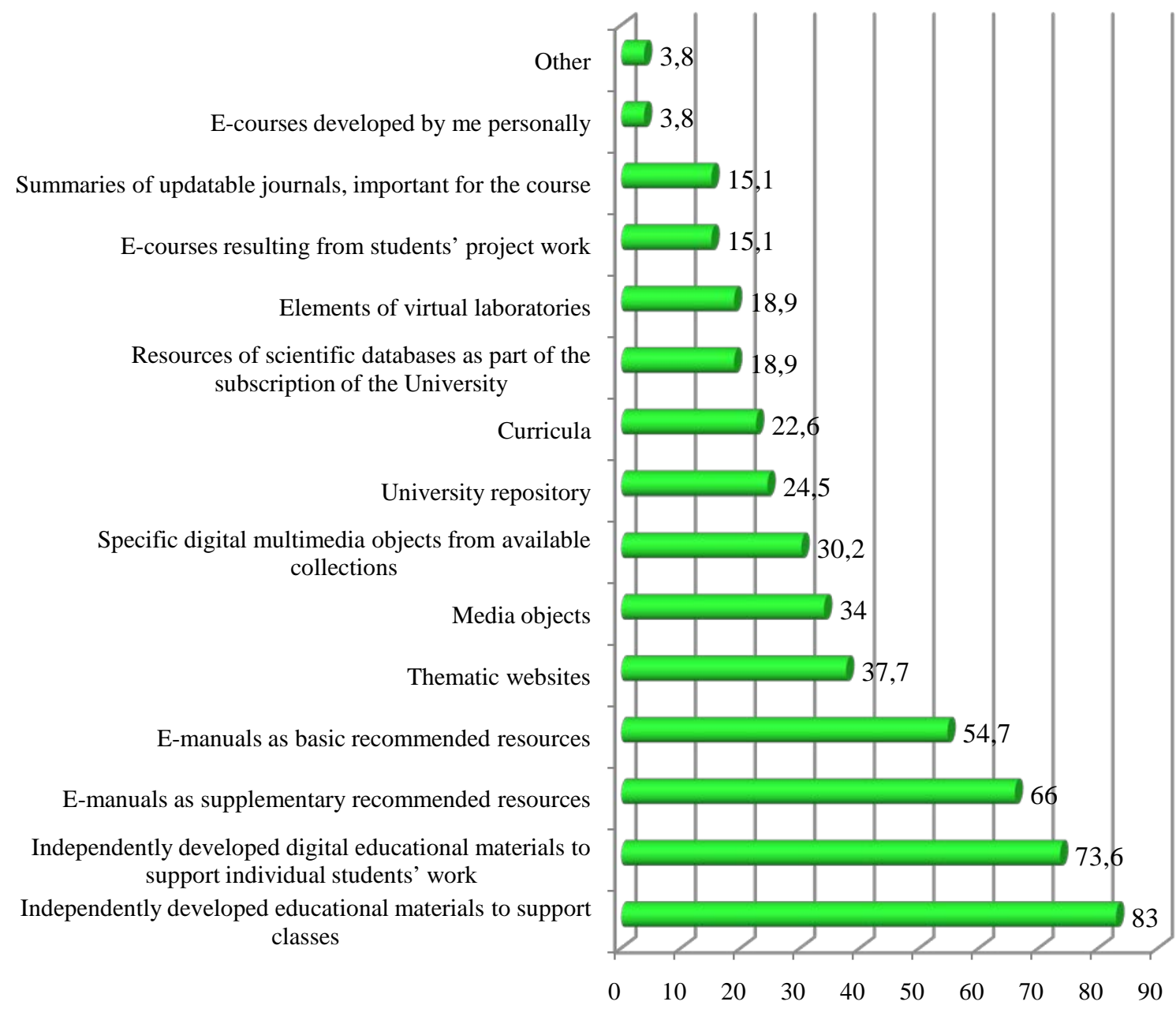

Fig. 1. The scope of ICT use in teaching (in \%)

In this context, we would like to elaborate on the advantages and disadvantages of using ICT in teaching aforementioned sociological disciplines. Sociology lectures in a technical university demand that professors overcome a number of objective difficulties. Teachers should present, usually verbally specific humanitarian material and help students develop a comprehensive understanding of the social problems without simplifying it.

It is through a combination of verbal narrative and illustrative material contained in the presentation that we can combine all the favorable conditions to help students understand and remember. Microsoft PowerPoint is a part of the most common tool package Microsoft Office it allows any modern teacher to create demonstration material for the lecture. Sociology lecturers use presentations to show visual materials, which were obtained during their scientific research. Classes get more vivid, intense and emotional if they are accompanied by multimedia presentations.

The text of multimedia slide can include the necessary terminology, complex terms with relevant explanatory comments. Given that the students in the classroom have different types of perception (visual and audial), using presentations to support lectures promotes efficient delivery of educational material and enables absolutely all audiences perceive the material 
displayed and narrated. Multimedia presentations give students the opportunity to present the most relevant results of sociological research in the form of graphs, charts, histograms and more. However, the presentation can trigger students' reflection because it allows students to switch attention from writing to analyzing the material presented the slide. This makes the learning process more diverse, attractive and dynamic, the one that stimulates creativity and promotes comprehensive professional training.

In addition, introducing the students, particularly those in Sociology, to multimedia presentations allows them to create their own style of presenting theoretical material with visual aids. This will help them in future professional activity, in particular in preparing publications based on the results of sociological research - reports for customers, press releases, publications in mass media and scientific journals.

In the framework of Bologna process and the European Credit Transfer System Ukrainian university professors should have substantial knowledge assessment tools for their students. These tools can be represented by tasks with objective criteria to evaluate the quality of performance and test materials to control students' knowledge. Using the control test method at practical classes and at lectures permits to evaluate large volume of knowledge and skills of the entire group of students; reduces psycho-physiological stress of both students and teachers; reduces the time required to do assessment which enhances teacher's productivity; improves the objectivity of assessment, which eliminates subjective attitude of the teacher; automates the process with the help of computer technology.

Computer testing as a special type of innovative testing is the most effective form of control, assessment and self-assessment of students' knowledge. In processing the results of assessment teachers can determine not only the amount of the acquired knowledge, but also the quality of obtained knowledge (the level is considered to be passed, if not less than $70 \%$ of the tasks are completed), and therefore, based on this they can plan their future work with students in the classroom.

The reality of modern world allows the teacher to use Internet resources for testing students using Web2.0. It is possible to create online self-tests to help you evaluate the quality of knowledge in sociology. Online testing allows you to make the whole process less stressful for students and less energy-consuming for the teacher. However, online testing significantly increases the motivation to study sociology. Students work more responsibly, and even weaker students try to get higher score, sometimes repeating the test more than once. Tests must be properly designed and adequately presented to students. In DSTU all students of social sciences have the opportunity to get acquainted with recommended educational aids and sets of teaching materials available on the information portal of the university.

Using this form of testing and preparation for it, each student is empowered to find out their grades and improve them, while correspondence students and those who missed classes can download materials and prepare for the final assessment. Overall, the tests motivate students to learn. According to A. Shemetev the introduction of test forms increased presence at lectures 3.4 times; student activity (by the number of scientific publications, student participation in conferences, students' initiatives in practical projects, participation in business games, general interest in material) - increased many times (Shemetev, 2014).

In current educational framework students' independent work is of great importance. In this context special role is played by textbooks and teaching aids that are recommended by the teacher. At the same time, the era of information and widespread Internet overshadow traditional library with paper books. Modern students are saving their time, they do not want to read in the library, and strive to do that in comfortable atmosphere and time. Considerable number of mobile applications make it possible that students get acquainted with educational literature in public transport via smartphones, tablets, laptops. That is why electronic textbooks - is an urgent need. 
It is important to emphasize that electronic manual is not an electronic version of the book, where all the information from the printed version is transferred into electronic mode or contains hyperlinks to the desired chapter. Depending on the type of training session (lecture, seminar, test, independent work) actual course of employment must be properly constructed to achieve the effect of using such assistance. With proper use electronic textbook, it can be a powerful tool for independent study of most subjects, especially those related to information technology (Mykhalyshcheva, Turukyna, 2013).

In our opinion, an electronic textbook on sociology should include a module with training material, module of internal assessment or self-assessment (questions, exercises, tests), the unit self (additional questions for self-study, a reference to the source), block with external assessment (exercise, laboratory work , tests). Such structure of the electronic manual provides a comprehensive study of social sciences. However, the use of electronic aids is not to replace the reference to primary sources and active learning methods.

Thematic sites permit not only look for information, but also solve many communication problems. Their use can increase the motivation of students, as its use in the classroom helps students feel immersed in the familiar environment of information technologies. Sites of e-learning libraries provide a wealth of material to prepare for seminars, discussions, independent work. Thanks to sites of periodicals students have access to the latest publications on relevant topics in sociological journals.

Regarding the use of media objects researchers call a complex of causes that determine the efficiency and feasibility of using videos as means of teaching students - among them the availability of video that can be recorded from various sources, stimulation of emotional and intellectual activity of students and developing in them personal attitude to certain problems in life, which is especially important within the course of sociology.

Films and videos contain examples of social life and interactions in different situations and circumstances. Videos allow you to analyze social status and social roles, isolate examples of social mobility and stratification and determine the specifics of various communities and so on.

The most successful work on films is going during the seminars as consolidation of theoretical knowledge, as well as in the context of individual work as a form of recapitulating the lecture material. Using film promotes skills of analysis, shaping opinions and the ability to argue their point of view.

Of course, for the film to become the medium of instruction and upbringing students, professors not only need to organize productive discussion of the narration and boost students' cognition on problematic issues and specific challenges, but also correctly select the content of the film, the place and time of use (Rassudova, 2014).

Continuing research into prospects of ICT use in teaching social sciences it is worth mentioning in particular the use of special software applications for sociology. According to the results of sociological survey we found that among ICT tools used by DSTU professors the most widely used are basic information tools such as programs from office suites, email, web search, etc. (Table. 1). In contrast to this, the use of information tools to manage educational process, electronic educational materials, specialized software and modern equipment and devices (networks, mobile technologies and so on.) is, unfortunately, on the average level.

To prepare and conduct of classes and organize instructional materials teachers of social sciences typically use standard software applications such as: Microsoft Word (text processing information, including office work, compiling reports after sociological research, analytical reviews etc.); Microsoft Excel (processing information presented in tables, including a variety of calculations, forms processing, etc.); Microsoft Access (creating and maintaining databases); Microsoft PowerPoint (creation and slide show presentations, various 
videos); web-browsers that provide access to global information resources of the Internet.

Table 1.

The level of use of various ICT instruments in teaching (based on the results of sociological survey)

\begin{tabular}{|l|c|c|c|c|c|}
\hline \multicolumn{1}{|c|}{ ICTs } & \multicolumn{5}{c|}{ Level of use (votes) } \\
\cline { 2 - 6 } & $\mathbf{1}$ & $\mathbf{2}$ & $\mathbf{3}$ & $\mathbf{4}$ & $\mathbf{5}$ \\
\hline $\begin{array}{l}\text { Basic information instruments (programs from office } \\
\text { suites, email, web search etc.) }\end{array}$ & 5 & 3 & 8 & 7 & 30 \\
\hline $\begin{array}{l}\text { information tools to manage educational process and } \\
\text { electronic educational materials }\end{array}$ & 9 & 5 & 18 & 11 & 10 \\
\hline specialized software applicable in those researched area & 12 & 8 & 10 & 12 & 11 \\
\hline $\begin{array}{l}\text { modern equipment and devices (networks, mobile } \\
\text { technologies and so on.) }\end{array}$ & 11 & 11 & 14 & 8 & 9 \\
\hline
\end{tabular}

Recently, the latest information technologies are used wider and wider to organize and conduct sociological research. Microsoft Excel as well as expert software SPSS for Windows, OCA for Windows and SOCIOLOG are applied for statistical analysis of the surveys. Teachers of social sciences as researchers and lecturers regularly use them in their activities and teach students to use them, especially in practical training.

OSA package is specifically designed for entry and statistical analysis of results of opinion polls, providing users with the tools to perform all the standard steps for processing sociological information. The package SPSS Statistics serves a broader purpose. It is designed for analysts and scientists, helping them to solve business problems and research tasks covering the whole analytical process. Powerful analytical tools of SPSS Statistics package help to simulate different situations and make better informed decisions. A key element of the package SPSS Statistics is SPSS Statistics Base, which provides access to data, data management and reporting similar to OSA. At the same time, SPSS Statistics Base can integrate additional modules to help plan data collection, implementation and dissemination of results. Mastering these tools is the key to preparing expert sociologists for comprehensive use of ICTs in professional activity (Sorokina, Karimov, Karimov, Zayarna, 2015).

An important factor that directly boosts the formation of students' ICT competence is the readiness of their non-technology teachers to widely use ICTs in their teaching practice. Unfortunately, today the majority of teachers use ICT in teaching their subjects fragmentarily, preferring computer diagnostics of knowledge, the exchange of information by e-mail, the using of electronic presentations and demonstration materials. Thematic websites, training programs, and other multimedia are rarely used. Personally developed electronic books and open educational resources are virtually unused Additional problems are associated with purely management issues, which include the degree of formation of the institution's electronic environment and the scope of regulation behind the use of electronic tools in teaching.

To mend this situation it is vital, above all, to unite all local networks of individual units in a single network of the educational institutions with electronic resources accessible to everyone, including e-library, various databases, information portal and more. Besides, there should be introduced regular review and consulting for teachers on how to use specific software in educational activities and on the latest ICT-based teaching techniques. It is important to support professors daily in their efforts to develop and use ICTs, to introduce an effective system of promotion of ICT instruments. 
The conclusions, recommendations, prospects for further research. The Use of ICTs and Internet resources today is a basic factor in teaching of social sciences as they improve the quality of education and reduce the time needed to embrace specific educational material. When planning and organizing students' work teachers have need to be aware that the new generation, permanently accompanied by mobile phones and computers, always require visual stimulation and dynamic educational process. ICTs contain invaluable advantages as they contribute to more profound involvement of students in the learning process, better understanding and remembering material, continuous interest in sociological disciplines.

ICT can be successfully used in a variety of classrooms with varying content, given professors evaluate the quality of mastering learning materials and monitor students' independent work. When teaching sociological disciplines in technical universities the main task of the teacher is to make learning not passive and mechanical, but active and creative. This is possible through the introduction of computer technologies and multimedia, which bring together not only the traditional static visual information (test, graphics), but also dynamic one (narration, video clips, animations). Thus, there arises the need to involve simultaneously the visual and auditory channels of students' perception which lets them develop dynamic images. Modern lecturers of sociology widely use individually developed digital materials to support classes (presentations, display materials) and students' independent work (digital textbooks, assignments, tests); recommend as basic and additional sources of information various e-manuals and related sites; some digital media training applications from available collections, university repository, electronic curricula and resources from research databases. The use of the aforementioned ICTs in teaching sociology enhances cognitive activity of students, develops research, creative potential, promotes more efficient formation of general and specific competencies. The use of ICT in the teaching of social sciences is the evidence of high professional level of modern teachers.

In view of the trends mentioned above the authors see prospects of further research into ICT use in teaching and learning in way of supporting professors' ICT competences and widening teacher-student network communication to support various learning goals.

Acknowledgments. The research leading to these results has received, within the framework of the IRNet project, funding from the People Programme (Marie Curie Actions) of the European Union's Seventh Framework Programme FP7/2007-2013/ under REA grant agreement No: PIRSES-GA-2013-612536.

\section{REFERENCES}

Ditkovsjka, L.A. (2013). Information-communication technologies in professional training of social workers. Collection of scientific papers of Khmeljnycjkyj institute of social technologies in institute "Ukraine”, № 1, 78-81 (in Ukrainian)

Korytnikova, N. (2012). Methodological problems and experience of using videos in teaching social sciences. In Ukrainian sociological journal, №1-2, 108-114 (in Russian)

Malikova, N.R. (2011). Innovative approaches in teaching sociology: from the experience of teaching in university. In SOCIS: sociological research, № 10, 120-126 (in Russian)

Mihalishheva, M.A. \& Turukina, S.V. (2013). Using electronic educational materials in technical schools. In Problems and prospects on the development of education. Proceedings of IV International scientific conference (Perm', July 2013), Perm': Merkurij, 127-129 (in Russian)

Rassudova, L.A. (2014). Film as a means of teaching students (case study of discipline Social Pedagogics ) In Personality, family and society : aspects of pedagogy and psychology : 
coll. of papers from XLII international scientific-practical conference, № 7(42), Novosibirsk: SibAK (in Russian)

Podlinjajeva, O. (2013). Didactic aspects of ICT use in professional activity of teachers of social-humanitarian sciences. In Pedagogy of higher and secondary school, Vol. 38, 247252 (in Ukrainian)

Slobodjanjuk, A.B. (2007). Experience using modern information-communication technologies in teaching sociological disciplines. In Modern information technologies and innovative methods of teaching in preparing professionals: methodology, theory, experience, problems. Coll. of scient. papers, Vol. 14, 415-419 (in Ukrainian)

Shemetev, A.A. (2014). Tests as an efficient instrument of knowledge evaluation in university students. In Modern scientific research and innovation, vol.2, retrieved May 15, 2017, from: http://web.snauka.ru/issues/2014/02/31055 (in Russian)

Shheglova, S.N. (2002). The use of Internet-technologies in teaching sociological disciplines. In SOCIS: sociological research, №4, 130-134 (in Russian)

Sorokina, L., Karimov, I., Karimov, G. \& Zayarna, I. (2015). Basic aspects of forming ICT-competences of sociologists. In IT tools - Good Practice of Effective Use in Education : Monograph, Katowice - Cieszyn, 261-270.

Voroncov, A.V. (2011). On the use of information technologies in teaching sociological sciences. In SOCIS: sociological research, № 6, 94-98 (in Russian) 